\title{
PENGENTASAN KEMISKINAN MELALUI USAHA AGROINDUSTRI DI KECAMATAN KAMPAR KABUPATEN KAMPAR PROVINSI RIAU
}

\author{
Dedi Zargustin, Mufti, Seprita Lidar ${ }^{1)}$ \\ ${ }^{1)}$ Staf Pengajar Fakultas Pertanian Univeritas Lancang Kuning, Pekanbaru \\ dedizargustin@yahoo.co.id, ir.mufti@yahoo.com, Sepritalidar@yahoo.com
}

\begin{abstract}
ABSTRAK
Penelitian ini dilakukan dengan tujuan : 1) untuk mengukur tingkat kemiskinan, 2) mengidentifikasi potensi dan kondisi sosial ekonomi serta minat masyarakat untuk melakukan usaha agroindustri. 3) Memilih potensi unggulan usaha agroindustri di Kecamatan Kampar Kabupaten Kampar.

Penelitian ini dilakukan di Kecamatan Kampar Kabupaten Kampar Provinsi Riau bulan Maret 2016 sampai dengan bulan Desember 2016, Anggota populasi adalah petani padi sawah yang berjumlah 300 KK. Sampel menggunakan Tabel Sekaran, U (1999), diperoleh $169 \mathrm{KK}$. Metode yang digunakan dalam penelitian ini adalah metode penelitian deskriptif dan kuantitatif. Penelitian ini disusun secara sistematis, spesifik, jelas dan terinci sesuai dengan prosedur penelitian, dimulai dari pra survey, observasi terstruktur dan wawancara terstruktur, tabulasi dan olahan data. Data diolah meliputi data tentang pendapatan, baik pendapatan utama maupun pendapatan dari pekerjaan alternatif dan lain-lain sumber pendapatan yang merupakan pendapatan rumah tangga. Sementara tingkat kemiskinan diukur dengan menggunakan konsep Sajogyo. Hasil olahan data akan dianalisis sampai kepada penarikan kesimpulan dan pelaporan.

Hasil penelitian menunjukkan bahwa tingkat kemiskinan masyarakat di Kecamatan Kampar 14,20 \% rumah tangga dikategorikan miskin, dan 85,80 \% tidak miskin. Selanjutnya teridentifikasi pula kondisi sosial ekonomi masyarakat terutama jenis pekerjaan alternatif yang dilakukan rumah tangga yaitu, 9,47 \% sebagai buruh tani, $7,70 \%$ supir, dagang $28,99 \%$, dan kegiatan industri kecil 53,85\%. Terpilihnya usaha agroindustri ikan salai sebagai potensi unggulan usaha agroindustri yang diminati oleh masyarakat di Kecamatan Kampar.
\end{abstract}

Kata Kunci : agroindustri,ikan salai, pekerjaan alternatif

\section{PENDAHULUAN}

Usaha pertanian masih tetap memegang peranan penting dalam pembangunan nasional khususnya di Provinsi Riau Secara usahaal, aktivitas ekonomi di Provinsi Riau tersebut sebenarnya disumbang oleh tiga usaha utama yaitu usaha pertanian 36.7 persen, usaha industri sebesar 32.7 persen dan usaha pertambangan sebesar 11.48 persen. Namun bila dilihat dari PDB Provinsi Riau termasuk minyak bumi ternyata sumbangan yang terbesar adalah usaha pertambangan sebesar 41.6 persen diikuti oleh usaha industri 20.8 persen dan usaha pertanian 20.7 persen (BPS, 2010).

Disatu sisi Provinsi Riau telah berhasil memacu pertumbuhan ekonominya bahkan diatas rata-rata nasional, dan meningkatkan pendapatan perkapitanya, bahkan sumbangan 
PDB Provinsi Riau tersebut sangat besar. Begitu pula apabila dicermati secara seksama situasi dan kondisi yang berkembang di satu sisi, Provinsi Riau juga memiliki berbagai kekuatan dan peluang yang menjanjikan kemajuan dan perkembangan yang pesat namun disisi lain seperti issu nasional, Provinsi Riau masih dihadapkan kepada masalah kemiskinan, yaitu dengan masih terdapatnya jumlah penduduk miskin yang relatif besar dimana pada tahun 2009 mencapai 1.008.321 jiwa atau 22,19 persen (BPS, 2010).

Selanjutnya, angka kemiskinan yang berlaku di Provinsi Riau tersebut, bila diamati menurut kabupaten/kota yang terdapat di Provinsi Riau, jumlah penduduk miskin yang relatif tinggi di Provinsi Riau, sebagian besar diantaranya terdapat di Kabupaten Kampar, dimana 18.89 persen diantaranya dikategorikan miskin..dengan mata pencaharian utama pada umumnya sebagai petani (Balitbang Provinsi Riau, 2011). Dari jumlah penduduk miskin tersebut, 15,41 persen diantaranya terdapat di Kecamatan Kampar sebagai salah satu kecamatan yang terdapat di Kabupaten Kampar

Masalah kemiskinan tetap menjadi persoalan utama di pedesaan. Umumnya fenomena kemiskinan melibatkan pelbagai jenis faktor diantaranya masih kurang keterlibatan masyarakat dalam melakukan pekerjaan alternatif (alternatif).

Pekerjaan alternatif yang dilakukan masyarakat sangat menentukan kemiskinan sebuah rumah tangga. Pendapatan rumah tangga yang berasal dari pekerjaan alternatif cukup besar kontribusinya terhadap pendapatan rumah tangga. Rumah tangga yang memiliki pekerjaan alternatif memiliki peluang lebih kecil untuk berada dalam kemiskinan jika dibandingkan dengan rumah tangga yang tidak memiliki pekerjaan alternatif.

Salah satu pekerjaan alternatif yang dapat meningkatkan pendapatan masyarakat adalah usaha agroindustri yang terdapat di pedesaan. Usaha agroindustri ini diharapkan akan dapat mengurangi kadar kemiskinan di pedesaan.

\section{METODE PENELITIAN}

Penelitian ini dilakukan di Kecamatan Kampar Kabupaten Kampar Provinsi Riau bulan Maret 2016 sampai dengan bulan Desember 2016, Anggota populasi adalah petani padi sawah yang berjumlah 300 KK. Sampel menggunakan Tabel Sekaran, U (1999), diperoleh $169 \mathrm{KK}$.

Metode yang digunakan dalam penelitian ini adalah metode penelitian deskriptif dan kuantitatif. Penelitian ini disusun secara sistematis, spesifik, jelas dan terinci sesuai dengan prosedur penelitian, dimulai dari pra survey, observasi terstruktur dan wawancara terstruktur, tabulasi dan olahan data. Data diolah meliputi data tentang pendapatan, baik pendapatan utama maupun pendapatan dari pekerjaan alternatif dan lain-lain sumber 
pendapatan yang merupakan pendapatan rumah tangga. Sementara tingkat kemiskinan diukur dengan menggunakan konsep Sajogyo. Hasil olahan data akan dianalisis sampai kepada penarikan kesimpulan dan pelaporan.

\section{HASIL DAN PEMBAHASAN}

\section{Luas Kepemilikan Lahan}

Lahan bagi masyarakat pedesaan merupakan faktor produksi utama dalam melakukan kegiatan usahatani. Demikian juga bagi masyarakat yang terdapat di Kecamatan Kampar, karena sebahagian besar masyarakatnya bertani padi sawah. Usahatani padi sawah sudah menjadi bagian dari kehidupan mereka sehari-hari (way of life). Rata-rata luas lahan adalah 0,21 Ha, dengan status kepemilikan lahan hak milik.

\section{Umur}

Umur sangat mempengaruhi produktivitas kepala rumah tangga. Pada umumnya kepala rumah tangga yang berusia relatif muda lebih produktif jika dibandingkan yang berusia tua.Ini akan mempengaruhi pula terhadap kegiatan usahatani padi sawah yang dilakukan oleh rumah tangga. Pada Tabel 1 diperlihatkan tentang umur kepala rumah tangga di Kecamatan Kampar.

Tabel 1. Umur Kepala Rumah Tangga Di Kecamatan Kampar.

\begin{tabular}{|c|c|c|}
\hline Umur & $\begin{array}{c}\text { Jumlah Kepala Rumah } \\
\text { Tangga }\end{array}$ & Persentase (\%) \\
\hline$<25$ & 9 & 5,33 \\
$26-30$ & 14 & 8,28 \\
$31-35$ & 15 & 8,88 \\
$36-40$ & 21 & 12,43 \\
$41-45$ & 35 & 20,71 \\
$46-50$ & 38 & 22,49 \\
$51-55$ & 21 & 12,43 \\
$>55$ & 16 & 9,47 \\
\hline Jumlah & 169 & 100 \\
\hline
\end{tabular}

Sumber : Data hasil olahan, 2016.

Berdasarkan Tabel 1 diketahui bahwa umur kepala rumah tangga di Kecamatan Kampar termasuk ke dalam umur produktif, yaitu 22,49 \% berumur antara 46-50 tahun, kemudian disusul yang berumur 41-45 tahun sebesar $20,71 \%$, serta $12,43 \%$ yang berumur 51-55 tahun.

\section{Tingkat Pendidikan}

Tingkat pendidikan yang dimiliki oleh kepala rumah tangga di Kecamatan Kampar dapat dilihat pada Tabel 2 sebagai berikut: 
Tabel 2. Tingkat Pendidikan Kepala Rumah Tangga di Kecamatan Kampar.

\begin{tabular}{|l|c|c|}
\hline \multicolumn{1}{|c|}{ Tingkat Pendidikan } & $\begin{array}{c}\text { Jumlah Kepala Rumah } \\
\text { Tangga }\end{array}$ & Persentase (\%) \\
\hline Tidak Pernah Sekolah & 33 & 19,53 \\
Sekolah Dasar (SD) & 71 & 42,01 \\
SMP & 39 & 23,08 \\
SMU/K & 23 & 13,61 \\
Perguruan Tinggi & 3 & 1,78 \\
\hline \multicolumn{1}{|c}{ Jumlah } & 169 & 100 \\
\hline
\end{tabular}

Sumber : Data hasil olahan, 2016.

Berdasarkan Tabel 2 diketahui bahwa tingkat pendidikan yang dimiliki oleh kepala rumah tangga cukup bervariasi yaitu mulai dari kepala rumah tangga yang tidak pernah bersekolah sampai perguruan tinggi. Tingkat pendidikan yang paling banyak dimiliki oleh kepala rumah tangga adalah tingkat pendidikan SD yaitu sebesar 42,01\%., kemudian 19,53\% tidak pernah sekolah.

\section{Pendapatan Usahatani Padi Sawah}

Di dalam suatu usahatani, perhitungan pendapatan atau penerimaan dan pendapatan bersih sangat penting. Hal ini disebabkan karena pendapatan bersama-sama dengan jumlah anggota keluarga merupakan faktor yang ikut menentukan di dalam menentukan pendapatan perkapita sebagai dasar penentuan tingkat kemiskinan rumah tangga. Pendapatan usahatani padi sawah terdiri dari pendapatan kotor dan pendapatan bersih. Pendapatan kotor adalah jumlah produksi pada usahatani padi sawah dikalikan dengan harga yang berlaku di daerah penelitian. Sedangkan pendapatan bersih adalah selisih dari penerimaan dengan semua biaya yang dikeluarkan rumah tangga dalam mengelola usahataninya yang meliputi biaya sarana produksi dan biaya tenaga kerja, baik tenaga kerja dari keluarga maupun luar keluarga. Tenaga kerja keluarga dihitung mengingat usahatani ini merupakan suatu business sehingga tenaga kerja yang berasal dari keluarga dianggap sebagai pengeluaran. Pada Tabel 3 diperlihatkan rata-rata jumlah jumlah pendapatan bersih usahatani padi sawah di Kecamatan Kampar.

Tabel 3. Rata-Rata Biaya Produksi, Pendapatan Kotor, Pendapatan bersih Usahatani Padi Sawah Di Kecamatan Kampar.

\begin{tabular}{|l|c|c|}
\hline No & Uraian & Jumlah \\
\hline 1 & Biaya Produksi (Rp) & 24.015 .384 \\
2 & Pendapatan Kotor (Rp) & 31.845 .000 \\
3 & Pendapatan Bersih (Rp) & 7.829 .616 \\
\hline
\end{tabular}

Sumber : Data hasil olahan, 2016

69 Pengentasan Kemiskinan Melalui Usaha Agroindustri Di Kecamatan Kampar Kabupaten Kampar Provinsi Riau 
Berdasarkan Tabel 3 rata-rata pendapatan bersih yang diterima rumah tangga adalah $\mathrm{Rp}$ 7.829.616. Pada umumnya rata-rata pendapatan bersih yang diterima oleh rumah tangga umumnya kecil bahkan mungkin negatif karena dalam pendapatan bersih yang diterima rumah tangga, tenaga kerja dalam keluarga dihitung sebagai pengeluaran usahatani.

\section{Pendapatan Rumah Tangga}

Pendapatan rumah tangga di dalam penelitian ini dihitung dengan menggunakan pendekatan penghasilan (earning approach). Penghasilan tersebut dapat berasal dari kegiatan usahatani pertanian maupun kegiatan di luar usahatani pertanian. Di dalam penelitian ini pendapatan rumah tangga terdiri dari pendapatan yang berasal dari usahatani ditambah dengan sumber pendapatan lain seperti pekerjaan alternatif, dari istri, anak dan usahatani di luar padi sawah. Pendapatan rumah tangga rumah tangga padi sawah dapat dilihat pada Tabel 4.

Tabel 4. Rata-Rata Pendapatan Rumah Tangga dan Perkapita Rumah tangga Di

\begin{tabular}{|l|l|l|}
\hline No & \multicolumn{1}{|c|}{ Kecamatan Kampar. } & \multicolumn{1}{|c|}{ Uumlah (Rp) } \\
\hline 1. & Pendapatan rumah tangga & 13.355 .060 \\
\hline 2. & Pendapatan Perkapita & 2.719 .231 \\
\hline
\end{tabular}

Sumber : Data hasil olahan, 2016

Berdasarkan Tabel 4 rata-rata pendapatan rumah tangga adalah $\mathrm{Rp}$ 4.732.100. Usahatani padi sawah tetap merupakan way of life dari aktivitas rumah tangga sehari-hari yang memberikan kontribsi dalam menambah pendapatan rumah tangga. Sementara ratarata pendapatan perkapita rumah tangga adalah Rp 2.19.231. Pendapatan perkapita ini relatif rendah jika dibandingkan pendapatan perkapita diluar usahatani padi sawah. Ada beberapa faktor yang menyebabkan rendahnya pendapatan perkapita, antara lain (1) Pada umumnya rumah tangga masih menggantungkan kehidupan pada sektor pertanian dengan mata pencaharian utama adalah tanaman padi sawah dengan produktivitas yang rendah (2) Masih belum terbukanya kegiatan usaha di luar pertanian sebagai mata pencaharian alternatif yang relatif baik. Meskipun telah ada pekerjaan di luar pertanian tetapi masih terbatas pada kegiatan berproduktivitas rendah.

\section{Mengukur Tingkat Kemiskinan Rumah Tangga}

Untuk dapat mengukur tingkat kemiskinan rumah tangga apakah termasuk kategori miskin atau tidak, penelitian ini akan mengkategorikan rumah tangga dalam empat tingkat sesuai dengan tingkat kategori yang dikemukakan oleh Sajogyo (Quibria 1996), yaitu tidak miskin, miskin, miskin sekali dan paling miskin. Harga beras Rp 7.000 
per kilogram menurut standar Depot Logistik Provinsi Riau pada bulan april 2015 akan digunakan sebagai standar dalam penelitian ini. Pendapatan tahunan rata-rata perkapita, yaitu jumlah pendapatan rumah tangga dari semua sumber pendapatan akan digunakan untuk mengukur kategori kemiskinan di lokasi penelitian.

Berdasarkan harga beras tersebut, tingkat kemiskinan di daerah penelitian dapat dikategorikan sebagai berikut:

1. Rumah tangga paling miskin. Pendapatan tahunan rata-rata perkapita lebih kecil daripada Rp 1.260.000 atau setara dengan penggunaan kurang daripada $180 \mathrm{~kg}$ beras setahun.

2. Rumah tangga miskin sekali. Pendapatan tahunan rata-rata perkapita antara $\mathrm{Rp}$ 1.260.000 hingga $\mathrm{Rp} 1.680 .000$ setara dengan penggunaan beras antara 180 hingga 240 kilogram beras setahun.

3. Rumah tangga miskin. Pendapatan tahunan purata perkapita antara Rp 1.680.001 hingga Rp 2.240.000 atau setara dengan penggunaan beras antara 241 hingga 320 kilogram beras setahun.

4. Rumah tangga tidak miskin. Pendapatan tahunan rata-rata perkapita lebih besar daripada $\mathrm{Rp} 2.240 .000$ atau setara dengan penggunaan beras yang lebih banyak dari 320 kilogram setahun.

Berdasarkan kepada kategori rumah tangga tersebut, pada Tabel 5 diperlihatkan tentang distribusi tingkat kemiskinan rumah tangga di lokasi penelitian.

Tabel 5. Tingkat Kemiskinan Rumah Tangga Di Kecamatan Kampar

\begin{tabular}{|l|l|c|c|}
\hline Nomor & Tingkat Kemiskinan & Jumlah Rumah Tangga & Persentase (\%) \\
\hline 1. & Miskin & 24 & 14,20 \\
2. & Tidak Miskin & 145 & 85,80 \\
\hline & Jumlah & 169 & 100 \\
\hline
\end{tabular}

Sumber : Data hasil olahan, 2016

\section{Identifikasi Potensi dan Kondisi Sosial Ekonomi Masyarakat}

Kondisi sosial ekonomi masyarakat akan sangat menentukan terhadap keberhasilan suatu usaha yang dilakukan oleh masyarakat. Kondisi sosial berkaitan dengan respon dan minat masyarakat untuk melakukan suatu usaha. Sedangkan kondisi ekonomi berkaitan dengan pekerjaan alternatif untuk menambah pendapatan rumah tangga.

Pekerjaan alternatif merupakan salah satu pekerjaan yang umumnya dilakukan oleh rumah tangga di luar pekerjaan utamanya sebagai rumah tangga. Pada umumnya mereka melakukan pekerjaan alternatif dengan alasan untuk menambah pendapatan rumah tangga karena tidak mencukupinya penghasilan dari pekerjaan utama. 
Pekerjaan alternatif yang dilakukan oleh rumah tangga cukup beragam, baik sebagai buruh tani, supir, dagang dan usaha agroindustri, sebagaimana terlihat pada Tabel 6 Berdasarkan Tabel 6 diketahui bahwa pekerjaan alternatif yang banyak dilakukan oleh rumah tangga adalah kegiatan dagang dan industri kecil dengan persentase masingmasingnya $28,99 \%$ dan $53,85 \%$. Usaha industri kecil yang dilakukan oleh rumah tangga terdiri dari usaha pembuatan kue, bengkel, agroindustri tahu, agroindustri ikan salai.

Tabel 6. Jenis Pekerjaan Alternatif Yang Dilakukan Rumah Tangga di Kecamatan Kampar.

\begin{tabular}{|l|l|c|c|}
\hline No & Jenis Pekerjaan Alternatif & Jumlah & Persentase (\%) \\
\hline 1. & Buruh Tani & 16 & 9,47 \\
2. & Supir & 13 & 7,70 \\
3. & Dagang & 49 & 28,99 \\
4. & Industri kecil & 91 & 53,85 \\
\hline & Jumlah & 169 & 100 \\
\hline
\end{tabular}

Sumber : Hasil olahan data, 2016

\section{Potensi Unggulan Usaha Agroindustri Rumah Tangga}

Berdasarkan hasil wawancara dengan 169 rumah tangga sampel dan tokoh masyarakat di Kecamatan Kampar, usaha industri yang paling banyak diminati oleh rumah tangga adalah usaha agroindustri ikan salai, walaupun usaha ini masih terbatas pada industri rumah tangga (home industry) namun cukup diminati oleh masyarakat. Cukup diminatinya usaha ini karena adanya dorongan dari pemerintah untuk menjadikan produk ini sebagai salah satu produk yang merupakan oleh-oleh khas masyarakat Kampar.

Kegiatan usaha agroindustri ini dilakukan dengan cara sangat sederhana dan dengan modal yang tidak terlalu besar.

\section{KESIMPULAN DAN SARAN}

\section{Kesimpulan}

1. Terukurnya tingkat kemiskinan masyarakat di Kecamatan Kampar, dimana 14,20 $\%$ rumah tangga dikategorikan miskin, dan $85,80 \%$ tidak miskin.

2. Teridentifikasi pula kondisi sosial ekonomi masyarakat terutama jenis pekerjaan alternatif yang dilakukan rumah tangga yaitu, 9,47\% sebagai buruh tani, 7,70 $\%$ supir, dagang $28,99 \%$, dan kegiatan industri kecil 53,85\%.

3. Terpilihnya usaha agroindustri ikan salai sebagai potensi unggulan usaha agroindustri yang diminati oleh masyarakat di Kecamatan Kampar. 


\section{Saran}

1. Perlunya aplikasi teknologi tepat guna dalam usaha agroindustri di Kecamatan Kampar sehingga produktivitas dapat ditingkatkan yang akan memberikan kontribusi terhadap pendapatan rumah tangga.

2. Pembinaan usaha agroindustri dari pemerintah setempat khususnya dari dinas koperasi dan dinas perindustrian dan perdagangan dapat lebih ditingkatkan lagi terutama dalam pemberian bantuan modal usaha.

\section{DAFTAR PUSTAKA}

Andi Nuhung, Iskandar. 2006. Bedah Terapi Pertanian Nasional, P.T BPI, Jakarta.

Badan Pusat Statistik. 2014. Berita Rasmi Statistik. No. 16/02/Th. XVII

Barro, J.R. and Sala-i-Martin, Xavier. 2011. Economic Growth. Cambridge: MIT Press.

Bernstein, H. 1971. Modernization Theory and the Sociological Study of Development, Journal of Development Studies, Vol.7 (2).

Chambers, Robert (2012). Poverty And Livelohood: Whose Reality Counis. Kuala Lumpur : Institute of development Studies

Chamhuri Siwar. 2013. 'Kemiskinan dan Pendidikan', dalam Asan Ali Golam Hassan (ed), Prognosis Pembangunan Dan Transformasi Struktur. Sintok: Penerbit Universiti Utara Malaysia.

Djojohadikusumo, Sumitro. 2006. Perkembangan Pemikiran Ekonomi Dasar, Teori Ekonomi Pertumbuhan dan Ekonomi Pembangunan. Jakarta: Penerbit Gramedia.

Hadiwegeno, Soetatwo \& Agus Pakpahan. 1999. Identifikasi Wilayah Miskin di Indonesia, Prisma Nomor 3, Tahun XII.

Sajogyo dalam Quibria, M.G. 1996. Rural Poverty In Asia: Indonesia, Republic of Korea, Philippenes and Thailand, Asian Development Bank, Manila.

Wiradi dalam Hagul 2010. Ketenagakerjaan Dalam Struktur Agraris di Perdesaan Jawa. Yogjakarta: Penerbit Yayasan Dian Desa.

World Bank. 2013. Country At A Glance, Indonesia. World Bank Web Page (10 Oktober 2013), http://www.worldbank.org/en/country/indonesia 